TERESA HEJNICKA-BEZWIŃSKA

Wydział Pedagogiki i Psychologii

Uniwersytet Kazimierza Wielkiego

Bydgoszcz

\title{
KONCEPCJA PEDAGOGIKI (I PEDAGOGIKI OGÓLNEJ) W SZKOLE LWOWSKO-WARSZAWSKIEJ
}

„W dzisiejszych czasach nie obowiązuje zasada ciągłego i kumulatywnego poszerzania wiedzy, mamy raczej do czynienia z procesem nieustannego zapominania i odzyskiwania”

(Bauman 2012, s. 8-9)

Streszczenie: W literaturze spotykamy różne definicje „pedagogiki ogólnej”, ale każda $\mathrm{z}$ tych definicji wiąże się z jawnym lub ukrytym pojmowaniem pedagogiki przez jej autora. W tym tekście przedstawiłam rozumienie pedagogiki (i „pedagogiki ogólnej”), które zostało wypracowane w procesie instytucjonalizacji i dyscyplinaryzacji pedagogiki w uniwersytetach II Rzeczypospolitej. Dojrzała koncepcja pedagogiki (i „pedagogiki ogólnej”) Kazimierza Sośnickiego spełniała kryteria wypracowane przez Szkołę LwowskoWarszawską, ale wydanie pracy przedstawiającej tę koncepcję w 1946 roku skazywało ją na zmarginalizowanie i odrzucenie.

Słowa kluczowe: proces instytucjonalizacji i dyscyplinaryzacji w nauce, pedagogia-pedagogika-pedagogika ogólna, system naukowy-system pedagogiczny-koncepcja.

\section{Wprowadzenie}

Inspiracją dla takiego sformułowania tematu była praca Wincentego Okonia (2000) Wizerunki sławnych pedagogów polskich, w której zostały zamieszczone dwa biogramy o tytułach: 1. Kazimierz Twardowski - nauczyciel uczonych (Okoń 2000, s. 447-470); 2. Kazimierz Sośnicki - uczeń Twardowskiego (Okoń 200o, s. 365-390). Tym, co łączy obydwa te nazwiska uczonych, jest Szkoła Lwowsko-Warszawska (SL-W). Krótka charakterystyka tej formacji intelektualnej zostanie przedstawiona w pierwszej części tekstu.

Motto artykułu sygnalizuje, że w recepcji owej formacji intelektualnej mieliśmy i mamy do czynienia z procesem zapominania i odzyskiwania pamięci o niej. Swoje 
rozważania skoncentruję jednak głównie na powstaniu i recepcji koncepcji pedagogiki (i „pedagogiki ogólnej”) Kazimierza Sośnickiego jako ucznia Kazimierza Twardowskiego i jednego z co najmniej 70 przedstawicieli tej szkoły (Woleński 2014, s. 13). Struktura niniejszego tekstu pokazuje, że koncepcja ta jest traktowana jako wytwór jednego uczonego, która ma uzasadnienie w szeroko rozumianym kontekście politycznym, kulturowym i społecznym pierwszej połowy XX wieku oraz w kontekście formacyjnym związanym z powstaniem SL-W. Moim zamierzeniem autorskim jest $\mathrm{w}$ związku $\mathrm{z}$ tym opisanie, wyjaśnienie i interpretacja związku owego kontekstu z koncepcją pedagogiki (i „pedagogiki ogólnej”), która została zaprezentowana przez Kazimierza Sośnickiego po II wojnie światowej. Uwarunkowania recepcji tej koncepcji okazały się jednak bardzo niekorzystne dla naukowej i pragmatycznej recepcji tej koncepcji.

Chciałabym też uprzedzić Czytelnika niniejszego tekstu, że odróżniam - zresztą za Kazimierzem Sośnickim - koncepcję dyscypliny naukowej i jej struktury od programu nauczania przedmiotów i podręczników akademickich, które tym programom odpowiadają. Dodam jeszcze, że od momentu wprowadzenia pedagogiki jako przedmiotu kształcenia w uniwersytetach obszaru niemieckojęzycznego (na przełomie XVIII i XIX wieku) moglibyśmy prześledzić, jak zmieniały się pomysły nauczycieli akademickich na realizację przedmiotów uznawanych za podstawowe dla wykształcenia pedagogicznego i pytać o związek tych zmian ze zmianami dotyczącymi koncepcji pedagogiki. Ten niezmiernie interesujący problem nie jest jednak przedmiotem mojego zainteresowania w niniejszym tekście, lecz jest nim koncepcja pedagogiki (i pedagogiki ogólnej) Kazimierza Sośnickiego, która znajduje uzasadnienie w tym, co łączy wszystkich przedstawicieli SL-W.

\section{Kulturowe uwarunkowania włączenia pedagogiki w zakres zainteresowań SL-W}

Jeżeli zgodzimy się co do tego, że geneza pedagogiki jako dyscypliny naukowej była związana z realizacją oświeceniowej idei postępu, kreowaniem świata nowoczesnego oraz reformą uniwersytetu jako instytucji, której skutkiem było powstanie i upowszechnienie Humboldtowskiego modelu tej instytucji jako uniwersytetu nowoczesnego (liberalnego), to moglibyśmy powiedzieć, że Polska pod koniec XVIII wieku utraciła szansę na uczestniczenie w dziele wprowadzania pedagogiki w struktury europejskich uniwersytetów. Rozbiory Polski na dziesięciolecia zamroziły nie tylko szanse na rozwój formy organizacyjnej państwa polskiego, lecz także procesy modernizacji, których skutkiem miało być przejście od społeczeństwa rolniczego do społeczeństwa industrialnego. Następstwem tego był podział polityczny terytorium między trzy imperia zaborcze oraz podział kulturowy, ponieważ ziemie

1 Takie zatytułowanie części pierwszej odsyła jednocześnie do szerszego opracowania tego tematu (Hejnicka-Bezwińska, 2014, s. 19-38). 
włączone do państw obszaru niemieckojęzycznego należały do państw stanowiących centrum kulturowe Europy Zachodniej, a ziemie pod zaborem rosyjskim znalazły się w państwie, które decydowało o kulturze Europy Wschodniej. Skutki tego podziału do dzisiaj są identyfikowane na ziemiach współczesnej Polski.

Posługując się kategorią pojęciową centrum cywilizacyjnego i peryferii, można sformułować tezę, że rozbiory Polski sprawiły pogłębienie się peryferyjności cywilizacyjnej wśród mieszkańców dawnych ziem państwa polskiego, ograniczając jeszcze bardziej szanse na uczestnictwo Polaków w procesie modernizacji. Sytuację tę tak opisuje Norman Davies: „Jak nigdy przedtem, dziewiętnastowieczna Europa pulsowała siłą - techniczną, gospodarczą, kulturalną, interkontynentalną. Podstawowymi symbolami tej potęgi były maszyny - lokomotywy, gazownie, dynama [...] Był to naprawdę tryumfalny «wiek siły» Europy. Prym wiodły najpierw Wielka Brytania - ów «warsztat świata» - a w następnych dziesięcioleciach Niemcy [...] Wśród przegranych i ofiar były wszystkie jednostki i wszystkie narody, które albo nie potrafiły się przystosować, albo nie umiały stanąć do współzawodnictwa - chłopi, rzemieślnicy/tkacze, miejska biedota, ludy zamieszkujące kolonie; Irlandczycy, Sycylijczycy, Polacy, którzy byli zmuszeni emigrować całymi milionami" (Davies 2002, s. 807-809).

Poszukiwanie identyfikacji tożsamościowych, wprowadzających pedagogikę w struktury akademickie polskich uniwersytetów, powiązane więc być musi z odwołaniem się do wydarzeń, które spowodowały, że wykorzystana została przez uniwersytety istniejące w Galicji względna autonomia tych ziem, uzyskana w latach 6o. XIX wieku. Środowiska uczonych skupionych w obydwu uniwersytetach galicyjskich (Uniwersytet Jagielloński w Krakowie oraz Uniwersytet Lwowski) mają swój ogromny wkład w podnoszenie poziomu świadomości społecznej poprzez kształcenie nauczycieli, szczególnie nauczycieli gimnazjów. We Wprowadzeniu zapowiedziałam jednak, że $\mathrm{w}$ tym tekście rezygnuję z omówienia roli uniwersytetów w pedagogicznym przygotowaniu nauczycieli do zawodu. Ten problem przedstawiłam w monografii (Hejnicka-Bezwińska 2015). Chcę ograniczyć się do przedstawienia roli Kazimierza Twardowskiego (1866-1938) jako „nauczyciela uczonych" i twórcy SL-W oraz Kazimierza Sośnickiego jako jego ucznia.

Kazimierz Twardowski studiował w Wiedniu. Po uzyskaniu stopnia doktora i stopnia doktora habilitowanego na Uniwersytecie Wiedeńskim został powołany na stanowisko profesora filozofii, pełniąc w latach 1895-1930 rolę kierującego katedrą, prodziekana, dziekana i rektora. Po roku 1930 pełnił funkcję profesora honorowego. Autorzy monografii poświęconych Kazimierzowi Twardowskiemu podkreślają, że podejmując pracę w Uniwersytecie Lwowskim, zaczynał w zasadzie od zera. Nie było w tej uczelni ani systematycznego kursu filozofii, ani seminarium filozoficznego, a jak wspominają jego uczniowie - sale wykładowe „świeciły pustkami”. Jeden $\mathrm{z}$ jego uczniów tak pisze o zaangażowaniu profesora $\mathrm{w}$ budowanie akademickiego statusu filozofii i nauk humanistycznych: „Linia dotychczasowa żywota profesora Twardowskiego - to obraz rezygnacji z wielkiej kariery naukowej w środowisku 
niemieckim i poświęcenie swych sił sprawie nauczania nauczycieli w Polsce. Dalszy krok ofiary - to rezygnacja $\mathrm{z}$ rozkoszowania się finezjami zagadnień spekulatywnych i oddanie się w zamian prozaicznej robocie u podstaw w społeczeństwie jednocześnie zaniedbanym, wynaturzonym i krnąbrnym. W końcu - wzięcie bezpośrednio na siebie robienia porządków w gromadzie ludzkiej, niemającej tradycji poprawnego współdziałania” (Kotarbiński 1958, s. 898).

Doświadczenie związane z poznawaniem filozofii i nauki świata Zachodniego oraz podejmowane problemy badawcze, jak również działalność organizacyjna i dydaktyczna związana z pełnieniem roli profesora skłaniały uczestników budowanej formacji intelektualnej do: 1) sprzeciwu wobec tej szczególnej odmiany „filozofii słowiańskiej” (obciążonej mesjanizmem, mistycyzmem, cierpiętnictwem); 2) sprzeciwu wobec braku logiki i odpowiedzialności za to, co jest mówione i pisane, nie tylko w tekstach kulturowych, lecz także w codziennym porozumiewaniu się ludzi (zjawisko to wyrażało się w ubóstwie językowym oraz w stosowaniu języka napuszonego, kwiecistego, obfitującego w bogate chwyty erystyczne); 3) pogodzenia się z tym, że wiek XIX przyniósł kryzys filozofii klasycznej (filozofii wielkich systemów filozoficznych); 4) zgody na to, że kryzys ten nie oznacza wcale końca filozofii, problemów filozoficznych i filozofowania; 5) odkrycia nowego wyzwania intelektualnego w budowaniu inaczej pojmowanych związków filozofii z nauką, a szczególnie z naukami humanistycznymi, które w tym czasie poszukiwały i kreowały swoją tożsamość dyscyplinową.

Podjęcie tych wyzwań sprawiło, że nie tylko zapełniły się sale wykładowe Uniwersytetu Lwowskiego, ale ukształtowała się nowa formacja intelektualna, której przedstawiciele mają swój znaczący udział zarówno w budowaniu tożsamości polskiej filozofii współczesnej i kształceniu profesjonalnych filozofów, jak i w instytucjonalizacji i dyscyplinaryzacji wielu innych dyscyplin naukowych, szczególnie w zakresie nauk humanistycznych.

Ubolewam nad tym, że znaczenie SL-W odkryli już i opisali filozofowie i psychologowie oraz przedstawiciele innych dyscyplin humanistycznych, ale tej lekcji - w moim przekonaniu - pedagodzy jeszcze nie odrobili do końca, chociaż trzeba zauważyć i z uznaniem odnieść się do faktu, że w 2014 roku odbyła się w Uniwersytecie Kazimierza Wielkiego w Bydgoszczy konferencja na ten temat pt. „Pedagogika w Szkole Lwowsko-Warszawskiej”.

W tym miejscu przypomnieć jeszcze muszę, że przedstawicieli SL-W nie łączyła żadna wspólna doktryna ani żaden światopogląd. Łączyła ich ogromna troska o język naukowy (jednoznaczną komunikatywność przekazu) oraz sposób dochodzenia do wyników badań, czyniący je możliwie najbardziej wiarygodnymi. O sile tej formacji intelektualnej decydowały głównie badania logików i psychologów. Jan Woleński tak pisze o twórcy SL-W: „Twardowski postawił sobie za cel nawiązanie kontaktu ze współczesną mu myślą filozoficzną. Zachęcał swoich uczniów, aby poznawali obce idee filozoficzne, ale bez podporządkowania się żadnej z dominujących filozofii z narodowego punktu widzenia, tj. niemieckiej, francuskiej lub brytyjskiej. 
[...] Ten stosunek do filozofii obcej (plus wiele innych czynników, a w szczególności entuzjazm dla budowy własnej tożsamości kulturowej po I wojnie światowej) sprawił, że filozofia polska po raz pierwszy w swoich dziejach znalazła się obok filozofii światowej, a nie pozostawała wobec niej spóźniona. To była olbrzymia historyczna zasługa Twardowskiego i jego uczniów, tym bardziej, że stworzył coś niemal z niczego" (Woleński 2014, s. 17-18).

Reforma uniwersytetów galicyjskich na przełomie XIX i XX wieku oraz powstanie Szkoły Lwowskiej (w latach 30. nazwano ją SL-W) i tzw. Polskiej Szkoły Matematycznej (powiązanej z nazwiskiem Stefana Banacha) pozwoliło na to, aby środowiska akademickie począwszy od 1916 roku bardzo poważnie zaczęły się przygotowywać do organizacji nauki i akademickiego kształcenia w Polsce, w tym czasie walczącej o niepodległość oraz możliwość budowania struktur demokratycznego państwa europejskiego i narodowej tożsamości.

\section{Udział SL-W w instytucjonalizacji i dyscyplinaryzacji pedagogiki}

Zasługą Twardowskiego - w moim przekonaniu - było stworzenie reguł i zasad kultury filozoficzno-naukowej, która w II Rzeczypospolitej pozwoliła na skuteczną instytucjonalizację pedagogiki w strukturach akademickich, a po II wojnie światowej przez dłuższy czas uzasadniała obronę akademickiego statusu pedagogiki w polskich uniwersytetach.

Wraz z odzyskiwaniem niepodległości na ziemiach włączanych do Polski pojawiały się nowe uniwersy tety (poza Uniwersytetem Jagiellońskim i Uniwersytetem Lwowskim - nazwanym później Uniwersytetem Jana Kazimierza). Już w 1915 roku władze niemieckie wyraziły zgodę na uruchomienie Uniwersytetu Warszawskiego (dokonało się to po wycofaniu wojsk rosyjskich i ewakuacji Cesarskiego Uniwersytetu Warszawskiego do Rostowa nad Donem). W 1918 roku został reaktywowany Uniwersytet Stefana Batorego w Wilnie, powołany został Uniwersytet Lubelski, nazwany później Katolickim Uniwersytetem Lubelskim, a w 1919 roku powołano Uniwersytet Poznański.

W ustawie z dnia 13 lipca 1920 roku o szkołach akademickich przyjęto organizację uniwersytetów, która wcześniej obowiązywała w uniwersytetach galicyjskich, a była to organizacja obowiązująca od roku $1863 \mathrm{w}$ uczelniach austriackich. Sankcjonowała ona humboldtowski model uniwersytetu. Kierującymi prawie wszystkimi katedrami filozofii i psychologii oraz większością katedr pedagogiki w wymienionych uniwersytetach zostali uczeni, o których możemy powiedzieć, że byli uczniami Twardowskiego lub w inny sposób byli związani z formacją przez niego stworzoną. Potwierdza to tezę Wincentego Okonia, który biogramowi tego uczonego nadał tytuł: Kazimierz Twardowski - nauczyciel uczonych (Okoń 2000, s. $447-470)$.

Pierwsza Katedra Pedagogiki i Dydaktyki powstała jednak w 1919 roku w strukturze Uniwersytetu Poznańskiego, a kierowanie nią powierzono Antoniemu 
Danyszowi (1853-1925). Do Poznania przeszedł on z Uniwersytetu Lwowskiego, gdzie zatrudniony był na stanowisku docenta. Po jego śmierci kierowanie katedrą przejął na krótko Bogdan Nawroczyński (1882-1974), a w latach 1927-1933 Ludwik Jaxa-Bykowski (1881-1948). W Uniwersytecie Lubelskim Katedrę Pedagogiki powołano w 1920 roku, a kierowanie nią powierzono Zygmuntowi Kukulskiemu (18901944). Kierował nią do 1939 roku. W Uniwersytecie Stefana Batorego w Wilnie Katedra Pedagogiki została powołana w 1925 roku, a kierowanie nią powierzono również Zygmuntowi Kukulskiemu. W 1938 roku Ludwik Chmaj (1988-1959) przejął kierowanie tą jednostką. Katedra pedagogiki (dokładniej: Katedra Pedagogiki i Organizacji Szkolnictwa) powstała w Uniwersytecie Warszawskim dopiero w 1926 roku. Jej organizację powierzono Bogdanowi Nawroczyńskiemu, który stopień doktora uzyskał pod kierunkiem Kazimierza Twardowskiego. W tym samym roku (1926) powołano też Katedrę Pedagogiki w Uniwersytecie Jagiellońskim. Kierował nią Zygmunt Mysłakowski. W struktury Uniwersytetu Jana Kazimierza w Lwowie Katedra Pedagogiki została włączona dopiero w 1938 roku, a kierowanie nią powierzono Bogdanowi Suchodolskiemu (1903-1992).

Odrębnymi instytucjami kształcenia i doskonalenia zawodowego nauczycieli na poziomie wyższym były: 1) Państwowy Instytut Pedagogiczny (PIP, 1918-1925); 2) Wolna Wszechnica Polska (WWP, 1919-1939); 3) Państwowy Instytut Nauczycielski (PIN, 1921-1927 i 1930-1935); 4) Państwowy Instytut Pedagogiki Specjalnej (PIPS, 1922-1939). Jedna tylko z tych szkół wyższych zawodowych uzyskała prawa akademickie do nadawania stopni i tytułów naukowych. Była to Wolna Wszechnica Polska (prawa te uzyskała w 1933 roku).

Z wprowadzeniem pedagogiki w struktury akademickie związana była kwestia nadawania stopni naukowych. Przejęta z obszaru niemieckojęzycznego organizacja uniwersytetów zakładała możliwość uzyskania stopnia doktora oraz możliwość poddania się procedurze habilitacyjnej. Małgorzata Przeniosło (2016) zwraca uwagę na nieco inną rolę habilitacji w II RP niż obecnie. Otóż habilitacja była nie tyle wskaźnikiem nowych osiągnięć naukowych, ale przede wszystkim wiązała się z uzyskaniem tytułu docenta, który uprawniał do prowadzenia wykładów w szkołach wyższych. Zgłaszający się do procedury habilitacyjnej musiał: 1) legitymować się stopniem doktora; 2) przedstawić wydrukowaną rozprawę habilitacyjną, uzyskać pozytywną opinię rady wydziału o posiadanych „kwalifikacjach osobistych”. Procedura habilitacyjna obejmowała: recenzje rozprawy, dyskusję nad rozprawą i wykład kandydata. Z czasem zaczęto wymagać pomyślnego zakończenia procedury habilitacyjnej od kandydatów do objęcia katedr jako jednostek organizacyjnych w strukturze uczelni.

Pomyślne zakończenie procedury habilitacyjnej upoważniało do uzyskania tytułu docenta i prawa do prowadzenia wykładów $\mathrm{z}$ danego przedmiotu. Tytuł docenta pedagogiki w 2o-leciu międzywojennym otrzymało pięć osób i byli to: Zygmunt Kukulski (UJK - 1925), Zygmunt Mysłakowski (UJ - 1925), Kazimierz Sośnicki (UJK - 1934), Mieczysław Ziemniewicz (UJK - 1935), Bogdan Suchodolski 
(UW - 1936). Tytuł docenta pedagogiki ogólnej w Wolnej Wszechnicy Polskiej uzyskał Bolesław Dobrowolski (1872-1954). Okoń jego biogram zatytułował: Antoni Bolesław Dobrowolski - teoretyk samokształcenia (Okoń, 2000, s. 67-96). W tym samym czasie uniwersytety nadały również 13 osobom tytuł docenta $z$ dyscyplin pokrewnych, m.in. z: historii (oświaty, pedagogiki, szkolnictwa w Polsce, wychowania, wychowania i doktryn pedagogicznych, wychowania i szkolnictwa, wychowania i szkolnictwa w Polsce), organizacji (szkolnictwa, wychowania), oświaty pozaszkolnej, pedagogiki eksperymentalnej, pedagogiki eksperymentalnej i dydaktyki nauk przyrodniczych. Uprawnienia do prowadzenia wykładów, które nie zostały uzyskane na państwowych uczelniach akademickich, weryfikowane były przez komisję powołaną przy MWRiOP pod względem formalnym, jeżeli kandydat chciał być zatrudniony w uczelni państwowej.

Proces instytucjonalizacji pedagogiki wskazuje, że w strukturze pedagogiki II Rzeczypospolitej (na poziomie habilitacji) zaczęły wyodrębniać się następujące zakresy problemowe: 1) ogólnych problemów pedagogiki (filozoficznych, historycznych, teoretycznych - w tym także związków teorii z praktyką); 2) dydaktyki i szczegółowych metodyk nauczania; 3 ) wiedzy o instytucjach tworzących system oświatowy; 4) historii praktyki edukacyjnej. Widać zatem, że proces instytucjonalizacji pedagogiki w strukturach akademickich II RP doprowadził do zakwestionowania struktury pedagogiki wypromowanej przez herbartystów, np. Wilhelma Reina (Sośnicki 1967, s. 24-44), chociaż niektórzy pedagodzy także i w latach późniejszych jeszcze do niej nawiązywali.

Powstanie katedr pedagogiki w uniwersytetach wymusiło świadomy udział pedagogów jako członków tych jednostek organizacyjnych w dyskursie o tożsamości pedagogiki jako dyscypliny naukowej. Ten problem $\mathrm{w}$ tym artykule musi być jednak pominięty, chociaż oczywisty wydaje się związek dyskursu o tożsamości pedagogiki z procesem instytucjonalizacji i dyscyplinaryzacji pedagogiki oraz kształtowaniem się koncepcji pedagogiki (i „pedagogiki ogólnej”).

\section{Status pedagogiki jako dyscypliny naukowej w II Rzeczypospolitej}

Zacznę od przypomnienia, że w kulturze europejskiej proces wprowadzania pedagogiki w struktury akademickie zaczął się w obszarze niemieckojęzycznym na przełomie XVIII i XIX wieku. Uruchomiony został praktyczną potrzebą lepszego przygotowania duchowieństwa i nauczycieli do tego, aby wzrósł ich autorytet i skuteczniejsze stało się ich oddziaływanie na to, co myślą i skłonni są czynić ludzie oraz grupy społeczne jako podmioty modernizacji, decydującej o stopniu realizacji oświeceniowej idei postępu. Dodajmy też, że „oświecanie” uznawano za najważniejszy czynnik przeprowadzanych reform państwowych, których celem było umocnienie struktur państwa, doskonalenie organizacji i coraz lepsze spełnianie ich funkcji. W Europie i Stanach Zjednoczonych humboldtowska reforma uniwersytetów oraz tworzenie systemu oświatowego, w pewnym stopniu (na określonym 
poziomie) powszechnego, bezpłatnego, zuniformizowanego i kontrolowanego przez państwo, były związane z realizacją interesów państwa. W Polsce troska o oświatę oraz akademicki status pedagogiki wiąże się z budowaniem i umacnianiem II Rzeczypospolitej (Hejnicka-Bezwińska 2015, s. 57-152).

Wcześniej zasygnalizowane zmiany związane z powstaniem SL-W pokazują, że dorobek i osiągnięcia ludzi tej formacji intelektualnej (oprócz wielu innych uwarunkowań) przyczyniły się w sposób znaczący do uruchomienia w latach 1915-1919 na ziemiach włączanych do niepodległego państwa polskiego aż czterech nowych uniwersytetów (Warszawa, Wilno, Lublin, Poznań). W dwudziestoleciu międzywojennym we wszystkich uniwersytetach powstały katedry pedagogiki jako jednostki powołane przede wszystkim do budowania statusu pedagogiki jako dyscypliny naukowej².

W tym miejscu muszę zwrócić uwagę na to, że katedry pedagogiki zostały powołane na polskich uniwersytetach II RP w latach 1919-1938, a więc około 100 lat później niż w uniwersytetach niemieckich. Najczęściej kierowali nimi uczniowie Twardowskiego lub osoby powiązane w inny sposób ze SL-W. Z tego powodu Twardowski został nazwany „nauczycielem uczonych” (Okoń 200o). Pamiętajmy też, że osób włączonych w tę formację intelektualną nie łączyła żadna doktryna ani żaden światopogląd, ani bezkrytyczne przenoszenie dorobku powstałego w innych uwarunkowaniach kulturowych i historycznych. O europejskim statusie SL-W zadecydowała oryginalność stworzonej przez to środowisko kultury filozoficzno-naukowej.

Przyczyną szczególnych uwarunkowań w budowaniu tożsamości pedagogiki polskiej jako dyscypliny naukowej w dwudziestoleciu międzywojennym były następujące wydarzenia:

- na przełomie XIX i XX wieku rozpoczęła się wielka krytyka herbartyzmu i szkoły tradycyjnej;

- idee pajdocentryzmu i rozwój psychologii eksperymentalnej sprzyjały wzrostowi zainteresowania pedologia (Milerski i Śliwerski 200o, s. 159; Hejnicka-Bezwińska 2015, S. 132-139);

- zmieniły się zdecydowanie założenia filozoficzne konstytuujące myślenie o procesach edukacyjnych przyjmowane przez twórców doktryn pedagogicznych powstałych w wielkim nurcie nowego wychowania" i amerykańskiego progresywizmu;

- powstawała i umacniała się pedagogika faszystowska we Włoszech i w Niemczech;

2 W niektórych katedrach realizowano również pedagogiczne kształcenie nauczycieli, ale często do kształcenia nauczycieli uniwersytety powoływały jednostki o nazwie „Studium Pedagogiczne”. Poza tym nauczycieli kształcono w liceach oraz wyższych szkołach zawodowych. Te formy kształcenia są chętnie opisywane przez historyków wychowania. 
- kształtował się nowy typ praktyki oświatowej podporządkowanej ideologicznej wizji budowania nowego człowieka, nazwany wtedy pedagogika sowiecka (Hessen i Hans 1934).

W tej niezwykle skomplikowanej sytuacji zmian nie do utrzymania był status pedagogiki wypracowany w obszarze niemieckojęzycznym i tożsamość pedagogiki herbartowskiej. Świadomość tego stanu miał z pewnością Kazimierz Sośnicki. Świadczy o tym jeden z jego artykułów zatytułowany Trzy hasła (Sośnicki 1936, s. 223-235). Autor tego artykułu wyróżnił w kulturze europejskiej trzy wielkie epoki i każdą z nich opisał za pomocą trójczłonowego hasła: 1) kulturę średniowiecza (chrześcijańską) charakteryzują: wiara, nadzieja i miłość; 2) kulturę czasów nowożytnych (racjonalistyczną) charakteryzują: wolność, równość i braterstwo; 3) kulturę nowej, wyłaniającej się ery charakteryzuje: autorytet, siła i władza. Dodać tylko można, że takie charakterystyki dla polskiej pedagogiki były odkryciem przełomu lat 80. i 90., a stało się to m.in. za sprawą tekstów Zygmunta Baumana, w których przedstawiał on dyskursy Zachodu związane z kryzysem - przełomem, ujawnionym przez postmodernizm, niezależnie od tego, jak go pojmujemy i na kogo skłonni jesteśmy się powoływać. Nie odzyskano jednak przy tej okazji pamięci o tekstach Sośnickiego i innych uczonych, mówiących o kryzysie modernizmu europejskiego.

\section{Koncepcja pedagogiki (i pedagogiki ogólnej) Kazimierza Sośnickiego}

Z poprzednio poczynionych ustaleń wynika, że Kazimierza Sośnickiego można nazywać uczniem Twardowskiego i przedstawicielem SL-W. Dojrzała koncepcja pedagogiki (i pedagogiki ogólnej) powstała jednak dopiero po II wojnie światowej. W odniesieniu do niej bardziej adekwatnym stwierdzeniem byłoby poinformowanie o opublikowaniu pracy, w której została ona przedstawiona (Sośnicki 1946). Kształtowanie się poglądów Sośnickiego na pedagogikę i praktykę edukacyjną przedstawiłam w oddzielnym artykule ${ }^{3}$. W tym miejscu tylko dodam, że stopień doktora filozofii uzyskał Kazimierz Sośnicki za pracę zatytułowaną Wyjaśnianie i opis w badaniach naukowych (1910, s. 128-148). Jego promotorem by1 Kazimierz Twardowski. Do procedury habilitacyjnej przystąpił w uniwersytecie Jana Kazimierza, na podstawie pracy Podstawy wychowania państwowego (Sośnicki 1933) i w 1934 roku otrzymał tytuł docenta pedagogiki.

Praca wydana przez Sośnickiego w 1946 roku (II wydanie w 1949), zatytułowana Pedagogika ogólna, jest efektem studiowania literatury (nie tylko w języku polskim), podróży studyjnych do uniwersytetów Francji, Niemiec i Szwajcarii (w latach

3 Artykuł ten został zatytułowany: Związek Kazimierza Sośnickiego ze Szkoła LwowskoWarszawską. Przygotowany został na konferencję zorganizowaną przez Zakład Pedagogiki Ogólnej UG w dniu 12 października 2017 roku, a jego tekst został złożony do druku w czasopiśmie „Przegląd Pedagogiczny”. 
1910-1911, 1912, 1930, 1935), pełnienia roli nauczyciela i dyrektora gimnazjum, naczelnika wydziału w Kuratorium Okręgu Lwowskiego, od 1929 roku profesora Uniwersytetu Jana Kazimierza we Lwowie, który osobiście doświadczył dramatu I i II wojny światowej oraz okupacji sowieckiej. Zasygnalizowania praca została wydana po podjęciu przez Profesora (i wielu innych profesorów Uniwersytetu Jana Kazimierza we Lwowie i Stefana Batorego w Wilnie) decyzji o opuszczeniu ziem bezpośrednio włączonych do ZSRR i osiedleniu się w Polsce jako państwie o ograniczonej suwerenności. Od 1945 roku związał swój los z budowaniem Uniwersytetu Mikołaja Kopernika w Toruniu. Omawiana praca miała służyć jako podręcznik akademicki.

Rekonstruując koncepcję pedagogiki (i pedagogiki ogólnej) przedstawioną w tym dziele, trzeba zacząć od przypomnienia, że jej autor odróżnia pedagogikę od pedagogii.

„Pedagogika jest teorią wychowania. Teorię przeciwstawiamy praktyce, tj. rzeczywiście wykonywanym czynnościom wychowania. Tę praktykę wychowania nazywamy także pedagogią" (Sośnicki 1946, s. 5).

W związku z tym odróżnia też system naukowy od systemu pedagogicznego: „Systemem naukowym nazywamy taki układ wiadomości, w którym wszystkie one są zestawione według jakiegoś porządku i między którymi porządek ten zaprowadza jakieś stosunki logiczne [...]. Systemy te są budowane według pewnej stałej zasady, od której zależy ich prawidłowość” (Sośnicki 1946, s. 114-115).

„Normy szczegółowe wychowania wraz z naczelnym ideałem tworzą system pedagogiczny. Ponieważ takich naczelnych idei pedagogicznych może być wiele, więc też rzeczywiście istnieją różne systemy pedagogiczne, różniące się bardzo między sobą w treści poszczególnych norm wychowania, w celach i środkach wychowania. Systemy wychowania stanowią teorię normatywną, gdyż każdy z nich podaje, co być powinno (Sośnicki 1946, s. 5).

Przyjmuje tė̇, że teoria naukowa może być: „[...] przypuszczeniem o bardzo dużym prawdopodobieństwie [...]. Przez teorię rozumiemy także to, co jest przez nas tylko pomyślane i przeciwstawiamy ją rzeczywistości, a zwłaszcza praktyce, przez którą rozumiemy działanie. Teoria bywa także używana w znaczeniu pewnego zespołu pojęć i praw naukowych, objętych przez pewną gałąź nauki. Jest ona naszym myślowym wytworem i nie ma na celu praktycznego działania" (Sośnicki 1946, s. 114).

Odwołując się do omawianej monografii i innych tekstów tego samego autora, skłonna byłabym odczytywać koncepcję jego pedagogiki jako naukę integrującą filozoficzność, teoretyczność, historyczność i praktyczność myślenia o edukacji. Pedagogika według tej koncepcji mogła być zarówno nauką opisową, jak i nauką normatywną. Jej przedstawiciele mogliby tworzyć systemy pedagogiczne o charakterze normatywnym, ale także badać systemy pedagogiczne istniejące jako koncepcje lub istniejące jako pedagogie (praktyki o różnym stopniu konceptualizacji i zwerbalizowania nazywane „pedagogiami”). 
W tym miejscu trzeba jeszcze dookreślić pojęcie koncepcji. Najbardziej precyzyjnie zostało ono zdefiniowane w dwugłosie nazwanym Sporem o pedagogikę ogólną. Sośnicki, odpowiadając Bogdanowi Suchodolskiemu na jego krytykę (1947, s. 179-181), tytułuje swój głos Proces czy koncepcja (Sośnicki 1947, s. 181-184). Polemizując ze stanowiskiem Suchodolskiego, który twierdził, że przedmiotem zainteresowania pedagogiki powinny być „procesy wychowawcze”, uzasadnia, że przedmiotem pedagogiki powinny być „koncepcje wychowania” i tak je definiuje: „[...] każda koncepcja wychowania jest teorią procesu wychowawczego. Sam proces jest rzeczywistym stawaniem się, zmianami zachodzącymi w uczniu wywołanymi przez jakieś warunki bądź to wewnątrz niego złożone, bądź też z zewnątrz na niego działające. [...] Koncepcja jest natomiast teoretycznym, myślowym ujęciem tej rzeczywistości w pewne ogólne pojęcia, prawa i prawidłowości” (Sośnicki 1947, s. 181).

Dodać trzeba jeszcze, że Sośnicki wyróżnia dwa poziomy ogólności. Pierwszego z nich można poszukiwać w każdym z normatywnych systemów pedagogicznych, a ujawnia się on w przyjmowanych założeniach światopoglądowych, orientacjach filozoficznych i wykorzystywanych teoriach. Drugi poziom ogólności może być osiągnięty w badaniach historyczno-porównawczych, których przykładem może być najważniejsza - w moim przekonaniu - praca tego autora, zatytułowana Rozwój pedagogiki zachodniej na przełomie XIX i XX wieku (Sośnicki 1967).

Podsumowując, w kontekście poczynionych ustaleń możemy przyjąć, że Kazimierz Sośnicki definiował pedagogikę postherbartowską jako dyscyplinę naukową, w ramach której uzasadnione jest tworzenie i kreowanie normatywnych systemów pedagogicznych, których ogólność wyraża się w tym, że powinny być ujawnione przyjmowane założenia. Możliwy jest jednak także inny poziom ogólności, który Sośnicki przypisuje pedagogice ogólnej, postulując, aby była ona nauką opisową. Mówi tak: „[...] nie posiadamy dotychczas jednego naukowego systemu pedagogicznego. Systemy pedagogiczne starają się więc utworzyć pewną teorię wychowania. Możemy jednak same te systemy uczynić przedmiotem naszych rozważań [...]. Takie rozważanie nad poszczególnymi systemami nie jest jedynie ich rejestracją i przedstawieniem ich treści. Traktuje je ono porównawczo i stara się zestawić ich właściwości i charakter, ich sens. Zadanie to spełnia pedagogika ogólna. Jest ona nauką opisującą, w odróżnieniu od normatywnego charakteru poszczególnych systemów" (Sośnicki 1946, s. 6).

Ostatnią kwestią, do której chcę odnieść się w niniejszym tekście, jest sprawa recepcji koncepcji pedagogiki (i pedagogiki ogólnej), jaką zaproponował Kazimierz Sośnicki.

\section{Recepcja koncepcji pedagogiki (i pedagogiki ogólnej) wypracowanej w SL-W}

Takie rozumienia pedagogiki i pedagogiki ogólnej nie mogły być przyjęte w warunkach politycznych ładu monocentrycznego i monopolu władzy jednej partii, działającej w ramach tzw. „obozu państw socjalistycznych”, w którym realną władzę 
sprawował Komitet Centralny Komunistycznej Partii Związku Radzieckiego, a jej narzucenie odbywało się w czasach terroru stalinowskiego.

Jeżeli zwrócimy uwagę na to, że książka ta ukazała się w 1946, to już wiemy, że wybór czasu wydania był najgorszym z możliwych, ponieważ:

- 5 lipca 1946 roku powołano Główny Urząd Kontroli Prasy, Publikacji i Widowisk;

- w 1947 roku omówiony wcześniej Spór o pedagogikę ogólna (SuchodolskiSośnicki) w czasopiśmie „Życie Szkoły” (1947, nr 7/8) zamieszczony został $z$ komentarzem redakcyjnym, że termin „pedagogika ogólna nie jest pojęciem ostrym”, a w tym samym numerze zamieszczona też została recenzja Romana Polnego, który krytykuje tę pracę, ponieważ nie służy ona „wychowaniu socjalistycznemu";

- w lutym 1947 roku powołano Komisję Kulturalno-Oświatową oraz odpowiedni wydział w Komitecie Centralnym PPR do przygotowania koncepcji „ofensywy ideologicznej”;

- w kwietniu 1949 roku Adam Schaff przedstawił na Plenum KC PZPR plan akcji „N” („rozkułaczenia nauki”, inaczej - likwidacji tradycyjnie rozumianej humanistyki);

- w październiku 1950 roku przy KC PZPR powstał Instytut Kształcenia Kadr Naukowych (zwany Instytutem Czerwonej Profesury),

- w dniach od 29 czerwca do 1 lipca 1951 roku odbył się I Kongres Nauki Polskiej, na którym Adam Schaff potępił Szkołę Lwowsko-Warszawską. Krytykę tej szkoły uznał za główne zadanie filozofii marksistowskiej i zapowiedział personalne rozprawienie się z jej przedstawicielami;

- 15 grudnia 1951 roku ogłoszona została ustawa o szkolnictwie, sankcjonująca wcześniej dokonane zmiany w strukturze, organizacji i funkcjonowaniu nauki i szkolnictwa wyższego, zmierzające do przejęcia wzorca sowieckiego (ograniczenia autonomii, wolności badań i podporządkowania modelu kształcenia celom polityczno-ideologicznym);

- w tym samym roku na liście 2500 książek wycofanych z obiegu czytelniczego znalazła się praca Kazimierza Sośnickiego zatytułowana Pedagogika ogólna.

Nie było zatem warunków do przeprowadzenia rzetelnej debaty nad koncepcjami pedagogiki i pedagogiki ogólnej Kazimierza Sośnickiego oraz wkładem SL-W w praktykę edukacyjną kształcenia pedagogów, nauczycieli, organizację i funkcjonowanie nauki oraz systemu oświatowego. Jan Woleński $(1985,2014)$ dowodzi, że koniec SL-W wyznacza rok 1939. Na pewno końcem nie jest śmierć twórcy tej szkoły w 1938 roku, jak również śmierć niektórych jej przedstawicieli, ani też opuszczenie Polski przez innych i dodaje: „[...] szkoła ta trwała w indywidualnych dokonaniach tych przedstawicieli, którzy przeżyli wojnę. Nie była to jednak formacja zorganizowana w taki sposób, jak to miało miejsce przed 1939 rokiem. Warunki polityczne powstałe po 1945 roku na pewno nie sprzyjały dalszemu trwaniu Szkoły 
Lwowsko-Warszawskiej. Z drugiej jednak strony mamy pewną pouczającą analogię. Zajęcie Austrii przez Hitlera spowodowało koniec Koła Wiedeńskiego, formacji filozoficznej w wielu punktach pokrewnej szkole stworzonej przez Twardowskiego. Nie odbudowało się ono jednak po II wojnie światowej, mimo że nie stały temu na przeszkodzie okoliczności polityczne. Wydaje się, że filozofia znacznie zmieniła się po II wojnie światowej" (Woleński 2014, s. 14).

Zasygnalizowane problemy wskazują na to, że recepcja koncepcji pedagogiki (i pedagogiki ogólnej) nie mogła odbywać się w warunkach wolności słowa, a zatem nie mogła być debatą naukową, a to wymaga zupełnie już innego opisu, wyjaśniania i interpretacji (Hejnicka-Bezwińska 2015, s. 153-362).

\section{Uwagi końcowe - epilog SL-W oraz koncepcji pedagogiki (i pedagogiki ogólnej) Sośnickiego}

Nie budzi wątpliwości fakt, że uwarunkowania polityczne sprawiły, iż modernizacja polskich uniwersytetów wraz z wprowadzaniem pedagogiki w struktury akademickie zaczęła się z prawie stuletnim opóźnieniem w stosunku do europejskiego obszaru niemieckojęzycznego, a szczególnie znaczącą rolę w procesie dyscyplinaryzacji i instytucjonalizacji pedagogiki odegrały dwa uniwersytety galicyjskie. Środowiska, które ten proces uruchomiły, łączyło poczucie odpowiedzialności za rozwój pedagogiki jako dyscypliny naukowej oraz kształcenie i doskonalenie zawodowe nauczycieli.

Zacznę od stwierdzenia, że uczeni SL-W w sposób pełnoprawny uczestniczyli w nauce europejskiej. Studia, podróże studyjne, znajomość języków sprawiała, że byli oni Europejczykami. O SL-W mówi się, że stworzyła typ kultury filozoficznej, która odgrywała w Polsce podobną rolę jako Koło Wiedeńskie w obszarze niemieckojęzycznym (Woleński, 2014). Sośnicki wszedł do SL-W wtedy, kiedy w euroamerykańskim obszarze kulturowym pojawiła się już krytyka „szkoły tradycyjnej” (herbartowskiej) toczyły się spory w ramach „nowego wychowania” i „progresywizmu”, a w Rosji kształtowała się zupełnie nowa pedagogia „wychowania komunistycznego"4. W tym kontekście pojawia się pytanie: A co z pedagogiką? Oddajmy w tej sprawie głos Profesorowi: „Kiedy zaczynałem ten zawód, a było to bardzo wcześnie w moim życiu, to właściwie pedagogiki nie było. Było nauczanie, była szkoła, ale systemu pedagogicznego - nawet mowy o systemie pedagogicznym nigdzie nie znalazłem. [...] Kiedy poszedłem na uniwersytet przede wszystkim zacząłem szukać takiej teorii i katedry pedagogiki. Niestety w tym czasie albo nie

4 O tych sporach napisze później Kazimierz Sośnicki pracę zatytułowaną Rozwój pedagogiki zachodniej na przełomie XIX i XX wieku (1967). O pedagogii „wychowania komunistycznego” Sergiusz Hessen wydał pracę w 1934 roku (Hessen i Hans 1934), natomiast Kazimierz Sośnicki napisał recenzję tej pracy i zamieścił ją w czasopiśmie: „Przegląd Pedagogiczny” 1934, nr LIII (18), s. $135-136$. 
było wcale katedr pedagogiki i przedmiot taki nie istniał, albo był w rękach takiego nauczyciela, który sam nie wiedział, jak to robić. Niestety była jedna teoria, którą znały podręczniki niemieckie - teoria herbartowska, Przyjęta na całym świecie [...] Pod koniec moich studiów zaczęła występować szkoła amerykańska „nowego wychowania”. To był już początek obecnego wieku” (Sośnicki 1974, s. 11-12).

W wyniku II wojny światowej przestał istnieć Uniwersytet Jana Kazimierza we Lwowie, a Lwów po II wojnie znalazł się poza granicami Polski. Profesora dotknęło osobiste nieszczęście związane ze śmiercią żony i syna. W 1945 roku podjął decyzję o opuszczeniu Lwowa. Wraz z innymi polskimi profesorami (Uniwersytetu Jana Kazimierza we Lwowie i Uniwersytetu Stefana Batorego w Wilnie), włączył się w budowanie Uniwersytetu Mikołaja Kopernika w Toruniu. Jednak w realizacji tego dzieła Profesorowie zmierzyć musieli się z procesem sowietyzacji oraz tzw. ofensywą ideologiczną. Procesy te objęły naukę, uniwersytety, instytucje systemu oświatowego i kulturę jako całość holistycznie rozumianą. Profesor odrzucił możliwość dokonania samokrytyki i potępienia swego wcześniejszego dorobku, a to skutkowało co najmniej marginalizacją i wyłączeniem go z tego, co Pierre Bourdieu (1984) nazwał kapitałem wynikającym $\mathrm{z}$ autorytetu nauki. Z tego powodu brakuje autorskiego głosu Kazimierza Sośnickiego w latach 50. Zamilkł na kilkanaście lat jako profesor pedagogiki i nie uczestniczył $\mathrm{w}$ debacie o zmianach w pojmowaniu pedagogiki i przedmiocie jej badań. Swoje najważniejsze dzieła publikował po przejściu na emeryturę, a więc w latach 60. i 70., ale to już wymaga nowej i innej narracji.

Dopiero w 1967 roku wydana została praca (Sośnicki 1967), która w moim przekonaniu jest egzemplifikacją przywołanego wcześniej rozumienia pedagogiki ogólnej. Jest to historyczno-porównawcza analiza czterech systemów filozoficznych: szkoły tradycyjnej - nowego wychowania - pedagogiki (pedagogii) faszystowskiej - pedagogiki (pedagogii) socjalistycznej. Kryterium systematyzacji i tworzenia struktury pedagogiki może też być - zdaniem Sośnickiego: 1) przedmiot badań; 2) metody badań; 3) specjalizacje. Jerzy Materne (2004, s. 137-143) stwierdził, jako znawca literatury niemieckiej, że systemy pedagogiczne wyodrębnione przez Sośnickiego wyprzedzają dokonania pedagogów niemieckich, ponieważ praca Detricha Bennera (w której wyróżnia on jako główne nurty współczesnej pedagogiki naukowej: p. empiryczną, p. humanistyczną i p. emancypacyjną) wydana została dopiero w 1973 roku i napisana została głównie w oparciu o teksty powstałe po II wojnie światowej.

Motto niniejszego tekstu czyni nas odpowiedzialnymi za to, co zapomnimy lub ocalimy od zapomnienia. Napisałam ten tekst w poczuciu obowiązku odzyskiwania pamięci o tym, co wydawało się ważne i być może nie utraciło swej ważności i powagi. 


\section{Bibliografia}

Bauman Z. (2012). Kultura jako praxis, tłum. J. Konieczny. Warszawa: WN PWN. Bourdieu P. (1984). Specyfika dziedziny naukowej i społeczne warunki rozwoju wie$d z y$, tłum. E. Neyman. W: Mokrzycki E. (red.). Kryzys i schizma. T. 2. Warszawa: PIW, s. 87-136.

Davies N. (2002). Europa. Rozprawa historyka z historiq̨. Kraków: Wydawnictwo ZNAK.

Hejnicka-Bezwińska T. (2014). Kulturowe uwarunkowania właczenia pedagogiki w zakres zainteresowań Szkoły Lwowsko-Warszawskiej. „Przegląd Pedagogiczny”, nr 1, s. 19-38.

Hejnicka-Bezwińska T. (2015). Praktyka edukacyjna w warunkach zmiany kulturowej. Warszawa: WN PWN.

Hessen S. i Hans M. (1934). Pedagogika i szkolnictwo w Rosji sowieckiej. Rozwój szkolnictwa sowieckiego izmiany komunistycznej polityki oświatowej od rewolucji październikowej do końca planu pięciolecia (1917-1932), tłum. A. Zieleńczyk. Lwów-Warszawa: Książnica - Atlas.

Kotarbiński T. (1958). Wybór pism. Warszawa: PWN.

Materne J. (2004). Pedagogika Kazimierza Sośnickiego i Romany Miller na tle zachodnioniemieckiej nauki o wychowaniu (Zarys zagadnienia). W: Rodziewicz E., Rzedzicka K., Zalewska E. (red.). Gdańskie rodowody pedagogiczne. Gdańsk: Wydawnictwo UG, s. 137-143.

Milerski B., Śliwerski B. (red.). (200o). Leksykon PWN. Pedagogika. Warszawa: WN PWN.

Okoń W. (200o). Wizerunki sławnych pedagogów polskich. Warszawa: Wydawnictwo Akademickie „Żak”.

Przeniosło M. (2016). Habilitacja $z$ pedagogiki w II Rzeczypospolitej. „Przegląd Pedagogiczny" nr 1, s. 41-55.

Sośnicki K. (1946). Pedagogika ogólna. Inowrocław: Księgarnia Wysyłkowa "Liberarium".

Sośnicki K. (1933). Podstawy wychowania państwowego. Lwów-Warszawa: Książnica - Atlas.

Sośnicki K. (1947). Proces czy koncepcja. „Życie Szkoły”, nr 7/8, s. 181-184.

Sośnicki K. (1974). Przemówienie prof. dra Kazimierza Sośnickiego na uroczystości $z$ okazji 9o-lecia jego urodzin $w$ dniu 30 maja 1973 r. na UMK w Toruniu. „Acta Uniwersitatis Nicolai Copernici. Pedagogika IV - Nauki Humanistyczno-Społeczne", z. 65.

Sośnicki K. (1967). Rozwój pedagogiki zachodniej na przełomie XIX i XX wieku. Warszawa: PZWS.

Sośnicki K. (1936). Trzy hasła. „Kultura i Wychowanie”, R. 3, s. 223-235.

Sośnicki K. (1910). Wyjaśnianie i opis w badaniach naukowych. „Przegląd Filozoficzny", nr XIII, s. 128-148. 
Suchodolski B. (1947). Pedagogika ogólna. „Życie Szkoły” nr 7/8, s. 179-181.

Woleński J. (1885). Filozoficzna Szkoła Lwowsko-Warszawska. Warszawa: PWN.

Woleński J. (2014). Szkoła Lwowsko-Warszawska z perspektywy historycznej. „Przegląd Pedagogiczny”, nr 1, s. 9-18.

\title{
THE CONCEPT OF PEDAGOGY (AND GENERAL PEDAGOGY) IN THE LVIV-WARSAW SCHOOL
}

\begin{abstract}
Literature presents us with various definitions of 'general pedagogy', yet each of them is connected to its author's open or hidden understanding of pedagogy. This text presents the interpretation of pedagogy (general pedagogy) developed in the process of institutionalisation and disciplinarisation at universities of the Second Polish Republic. The mature concept of pedagogy (and general pedagogy) of Kazimierz Sośnicki fulfilled the criteria laid down by the Lviv-Warsaw School. However, it was marginalised and rejected due to the fact that a paper presenting this concept was published in 1946.
\end{abstract}

Key words: institutionalisation and disciplinarisation process, education - pedagogy general pedagogy, scientific system - pedagogical system - concept.

Teresa Hejnicka-Bezwińska - prof. dr hab., em. prof. zw. Uniwersytetu Kazimierza Wielkiego w Bydgoszczy. Najważniejsze publikacje: Praktyka edukacyjna w warunkach zmiany kulturowej (w poszukiwaniu logiki zmian) (2015); O zmianach w edukacji. Konteksty zagrożenia i możliwości (200o); Tożsamość pedagogiki. Od ortodoksji ku heterogeniczności (1997). Adres e-mailowy: bezwinska@poczta.onet.pl. 